\title{
PVC/COPPER OXIDE COMPOSITES AND THEIR EFFECT ON BACTERIAL ADHERENCE
}

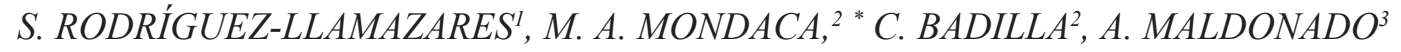 \\ ${ }^{I}$ Center Research of Advanced Polymers (CIPA), Conicyt-Regional R08C1002, Cordillera Av. 2634, Parque Industrial Coronel, Coronel, \\ P.O. Box 4051, Post 3, Concepción, Chile. \\ ${ }^{2}$ Environmental Microbiology Laboratory, Microbiology Department, University of Concepción, P.O. Box 160-C, Post 3, Concepción, Chile. \\ ${ }^{3}$ Unidad de Desarrollo Tecnológico, University of Concepción, 2634 Cordillera Av., Parque Industrial Coronel, Coronel, P.O. Box 4051, \\ Post 3, Concepción, Chile. \\ (Received: November 15, 2011 - Accepted: March 25, 2012)
}

\begin{abstract}
In this work, $\mathrm{PVC} / \mathrm{CuO}$ and $\mathrm{PVC} / \mathrm{Cu}_{2} \mathrm{O}$ composites were prepared by melt-blending method. The results of scanning electron microscopy (SEM) - X ray energy dispersive spectroscopy (EDS) Cu-mapping showed that the composites are a hybrid of the polymer and the copper oxide particles, and these particles were distributed uniformly in the polymer matrix. The adherence of Escherichia coli ATCC 25922 on the surface of composite materials was assessed through the inventory of adhered viable cells and SEM analysis. In PVC/copper oxide composite, the number of adhered bacterial cells was reduced by almost 2 units $\log _{10}$ with regard to those adhere to the pure PVC polymer. SEM images of composite materials showed a significant decrease in bacterial adherence when compared to the pure polymer. It was also found through transmission electron microscopy (TEM) images to that $E$. coli incubated in the presence of cuprous oxide $\left(\mathrm{Cu}_{2} \mathrm{O}\right)$ and cupric oxide $(\mathrm{CuO})$ microparticles go through structural and morphological changes at the membrane level. Bacterial cells incubated in the presence of $\mathrm{Cu} \mathrm{O}_{2} \mathrm{O}$ were bacillary with blunt ends, and their size was reduced by $30 \%$ when compared to those incubated in the absence of copper oxides. The results obtained indicate that the PVC/copper oxide composites inhibit the adhesion of E. coli to their surface.
\end{abstract}

Key words: Bacterial adhesion, PVC/copper oxide composite materials, E. coli.

\section{INTRODUCTION}

The effectiveness of copper and its oxides to inhibit the increase of pathogenic microorganisms has become an ideal candidate to be used as a active biocide in polymer matrices ${ }^{1,2,3}$. Currently, the biocidal property of copper and its oxides is used in the design of polymer materials for biomedical devices, ${ }^{4}$ in bactericide textiles ${ }^{5}$ and antifouling paints, ${ }^{6,7}$ to name a few.

The adhesion is the first step of bacterial pathogenesis and depends on the nature of the material surface and the bacteria involved. ${ }^{8}$ Once adhered, they proliferate forming groups of cells (microcolonies) on the surface, which are then embedded in an extracellular matrix secreted by them, forming biofilms. These biofilms give them protection against external agents. ${ }^{9}$

The strategies for the elimination of biofilms consist basically in preventing the initial adhesion (material handling, use of antibiotics or anticoagulants), restricting bacterial multiplication and aggregation and the management of specific bacteriophages. ${ }^{10}$ The search for materials, that inhibit the formation of biofilms is one of the most promising strategies in the health area, because with them the surface bacterial colonization in the different medical devices would be prevented. The polymer composite materials that have copper incorporated as the active element are an attractive option in the development of materials for medical devices.

Several methods are available for the preparation of composite materials, such as solution processing and melt blending. ${ }^{11}$ The last one has advantage that is environmental benign (free of solvents) and it is melt conventional process in the polymer industry for conventional thermoplastic, among others polyethylene, polypropylene, polyvinyl chloride (PVC). ${ }^{12}$ Thus, for example, $\mathrm{X}$. Che et al. ${ }^{13}$ (2004) reported the preparation of PVC/antibacterial particles composite by melt-blending method, zirconium phosphate containing silver which was used as antibacterial particles.

However, preparation of conventional polymer/metal composite by melt mixing has shown poor dispersion of metal particles. ${ }^{14}$ The dispersion of antimicrobial metal in polymer is critical for development a novel polymer material with uniform properties. On the other hand, in polymer/metal composites, there is a risk that the metal is completely covered by the polymer, avoiding that copper its role as a biocide agent. ${ }^{15}$ In this report the authors found copper alloys is superior than polymer-containing nanoparticulate silver in their antimicrobial potential. However.

There are still pending challenges in the development of biocide polymer composite materials, where copper acts as an active agent inhibiting bacterial adhesion during the lifespan of the product. This study evaluated the adhesion of Escherichia coli ATCC 25922 on the surface of $\mathrm{PVC} / \mathrm{CuO}$ and $\mathrm{PVC} / \mathrm{Cu}_{2} \mathrm{O}$ composites and the antibacterial effect of copper oxides.

\section{EXPERIMENTAL}

Preparation and characterization of PVC/copper oxide composites

Commercial PVC powder supplied by Tecnocom S.A. Argentina under a trade name of z7500 was used as polymer matrix. The processing additive including dioctyl phthalate, epoxidized soybean oil, magnesium stearate, zinc stearate and stearic acid were of technical grade products. Copper oxides, $\mathrm{Cu}_{2} \mathrm{O}$ and $\mathrm{CuO}$, supplied by Quipasur, Chile were employed as antimicrobial additives. The dosage for the preparation of PVC compound (neat) and $\mathrm{PVC} /$ copper oxide composites are summarized in Table I.

Table I. Compositions of neat PVC and PVC/copper oxide composites.

\begin{tabular}{|c|c|c|c|}
\hline Ingredients & \multicolumn{3}{|c|}{ Samples } \\
\hline (parts per hundred) & Neat PVC & PVC/ $\mathrm{Cu}_{2} \mathrm{O}$ & $\mathrm{PVC} / \mathrm{CuO}$ \\
\hline PVC & 100 & 100 & 100 \\
\hline Dioctyl phthatalate & 53 & 53 & 53 \\
\hline Epoxidized soybean oil & 6.7 & 6.7 & 6.7 \\
\hline Magnesium stearate & 0.3 & 0.3 & 0.3 \\
\hline Zinc stearate & 0.4 & 0.4 & 0.4 \\
\hline Stearic acid & 0.33 & 0.33 & 0.33 \\
\hline Cuprous oxide & - & 1.6 & - \\
\hline Cupric oxide & - & - & 1.6 \\
\hline
\end{tabular}

phr: per hundred resin

At first, PVC resin, processing additives and copper oxide (except for PVC compound) were dry-blended in a high speed mixer until making a homogenous mixture, then were melt-blended in a twin-screw extruder. The blending temperature profiles from hopper to die zones in the extruder were $120,130,140,145,150$ and $150{ }^{\circ} \mathrm{C}$. The screw rotating speed was $60 \mathrm{rpm}$. The PVC products were pelletized and solidified by passing through a coolingsystem.

Pellets of PVC compound and PVC/copper oxide composites were compression molded at $145{ }^{\circ} \mathrm{C}$ for $3 \mathrm{~min}$, followed by cooling to room temperature to obtain sheets with thickness of $1 \mathrm{~mm}$ and cut into $1 \mathrm{~cm} \mathrm{x} 1 \mathrm{~cm}$ strips. The strips were used in microbiology assay. 
The fractured surface in liquid nitrogen of composite material plates were observed in a scanning electron microscope Joel JSM 6300 LY (Tokyo, Japan). For this purpose, the samples were covered with a gold film of $40 \mathrm{~nm}$-thick in a sputter coater S5150 equipment. A mapping of the surface was carried out in an area of $105 \times 75 \mu \mathrm{m}\left(\mathrm{PVC} / \mathrm{Cu}_{2} \mathrm{O}\right)$ and $31 \times 20 \mu \mathrm{m}(\mathrm{PVC} / \mathrm{CuO})$ using the X-ray energy-dispersive spectroscopy (EDS) to determine the degree of dispersion and distribution of copper particles in the polymer matrix. In addition, the chemical composition of PVC composite materials was determined in the selected areas through EDS.

\section{Microbiology assay}

Escherichia coli ATCC 25922 strain was grown in trypticase broth and incubated at $25{ }^{\circ} \mathrm{C}$ for 24 hours, to be used as inoculum in adhesion assays.

Pieces of neat PVC and composite materials were incorporated into the flasks containing $100 \mathrm{ml}$ of culture medium previously inoculated with $E$. coli adjusted to $1 \times 10^{5} \mathrm{CFU} / \mathrm{ml}$ with bacterial strain growing in exponential phase. These flasks were incubated at room temperature with a constant stirring of $120 \mathrm{rpm}$. After 1, 2, 4, 8 and 15 days of incubation, the pieces of the polymer material were taken with sterile forceps and were washed with plenty of sterile and sonicated (Elma Transsonic 310) for $10 \mathrm{~min}$, to ensure the removal of nonadherent bacterial cells. Subsequently, viable cells were counted using a microdrop technique ${ }^{16}$, the result was the average of three determinations, expressed as colony forming units per $\mathrm{ml}(\mathrm{CFU} / \mathrm{ml})$.

On the other hand, pieces of neat PVC and composite materials, taken at different incubated times, were fixed directly in $2.5 \% \mathrm{v} / \mathrm{v}$ of glutaraldehyde and observed by SEM.

The test to determine the effect of copper oxides on the bacterial cell was performed using flasks with $50 \mathrm{ml}$ of culture medium inoculated with $E$ coli with and without copper, the copper oxide concentration was $320 \mu \mathrm{g} / \mathrm{ml}$ according to the literature. ${ }^{17}$ The flasks were incubated at $25^{\circ} \mathrm{C}$ for 24 hours. Subsequently, bacterial cells were washed three times with sterile water and fixed in glutaraldehyde at $2.5 \% \mathrm{v} / \mathrm{v}$. Samples were analyzed by transmission electron microscopy (TEM) using a JEOL-JEM 1200 EX II microscope (Jeol Technics Ltd, Tokyo, Japan) and by SEM.

\section{RESULTS AND DISCUSSION}

$\mathrm{PVC} / \mathrm{CuO}$ and $\mathrm{PVC} / \mathrm{Cu}_{2} \mathrm{O}$ composites were prepared using the meltblending method and in both cases showed a uniform color. As expected the $\mathrm{PVC} / \mathrm{CuO}$ composite showed a black color characteristic of $\mathrm{CuO}$, while the $\mathrm{PVC} / \mathrm{Cu}_{2} \mathrm{O}$ composite had a red color characteristic of $\mathrm{Cu}_{2} \mathrm{O}$. SEM images did not distinguish isolated or aggregated copper oxide particles. Furthermore, there was no phase separation observed in these composites.

In the EDS mapping, samples of $\mathrm{PVC} / \mathrm{CuO}$ (Figure 1) and $\mathrm{PVC} / \mathrm{Cu}_{2} \mathrm{O}$ (Figure 2) composites, small dots were observed which corresponded to copper, evenly distributed in the selected areas, suggesting an homogeneous distribution of copper in both composite materials. However, the copper concentration in the composite materials varied, where $0.68 \%$ was in an area of $105 \times 75 \mu \mathrm{m}$ for the $\mathrm{PVC} / \mathrm{Cu}_{2} \mathrm{O}$ composite material and $0.58 \%$ in $31 \times 20 \mu \mathrm{m}$ for the $\mathrm{PVC} / \mathrm{CuO}$ composite material. The reduction in the amount of copper of a composite material with regard to the other may be associated to the lowest proportion of copper in the $\mathrm{CuO}$ with regard to $\mathrm{Cu}_{2} \mathrm{O}$.

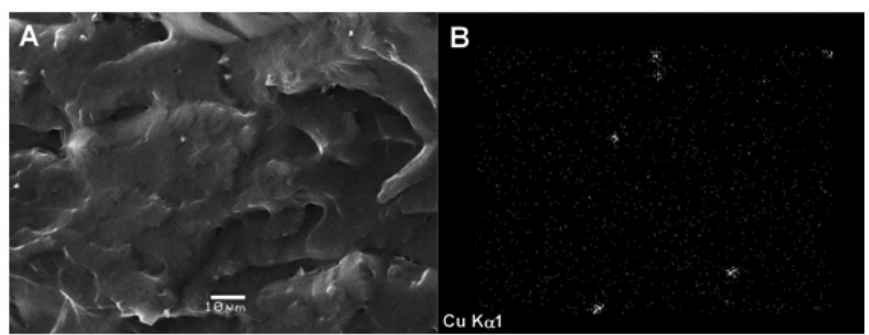

Figure 1. SEM-EDS mapping of $\mathrm{PVC} / \mathrm{CuO}$ composite with $1 \mathrm{wt} \%$ of $\mathrm{CuO}$ : (a) SEM image and (b) the corresponding EDS mapping of copper.

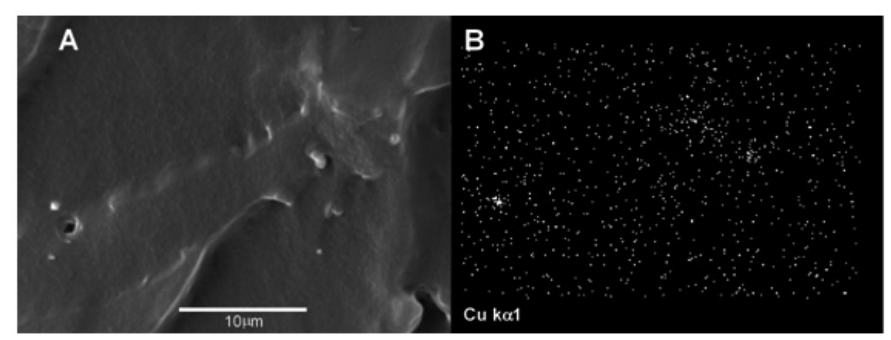

Figure 2. SEM-EDS mapping of $\mathrm{PVC} / \mathrm{Cu}_{2} \mathrm{O}$ composite with $1 \mathrm{wt} \%$ of $\mathrm{Cu}_{2} \mathrm{O}$ (a) SEM image and (b) the corresponding EDS mapping of copper.

The adhesion of E. coli on the surface of PVC/copper oxide composites was studied through SEM images taken at the surface of these composites, which were introduced in culture media previously inoculated with $E$. coli $\left(1 \times 10^{5} \mathrm{UFC} / \mathrm{ml}\right)$ in exponential growth phase. Figure 3 shows that the proportion of bacteria adhered to the PVC composite material after 2 days are lower than those adhered on neat PVC. In the $\mathrm{PVC} / \mathrm{Cu}_{2} \mathrm{O}$ composite, the amount of adhered bacteria was slightly lower.
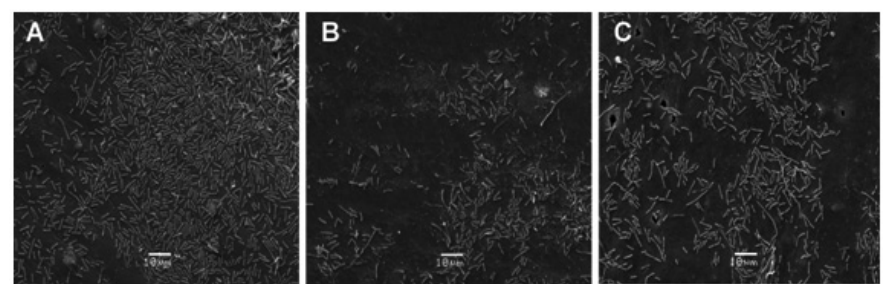

Figure 3. SEM images of the adhesion of E.coli ATCC 25922 after 2 days on: neat $\mathrm{PVC}(\mathrm{A}), \mathrm{PVC} / \mathrm{Cu}_{2} \mathrm{O}$ composite (B) and $\mathrm{PVC} / \mathrm{CuO}$ composite (C).

Figure 4 shows the kinetics of the biofilm formation on the surface of the tested materials. After 24 hours of incubation, biofilms are formed and they are stable for 15 days. The viable cell counts, expressed as $\log _{10} \mathrm{CFU} / \mathrm{ml}$, showed that on the composite material the number of adhered cells decreased by almost two $\log _{10}$ when compared to neat PVC. The results of the kinetics of biofilm formation are similar to those reported for other Gram-negative bacteria. ${ }^{18}$ It is important to note that the time required to form biofilms was short in relation to previous reports from Mondaca et al. ${ }^{19}$ with Serratia sp. using activated carbon as inert substrate, which was 7 days. The time required to have mature biofilms varies due to the adhesion, depending on the type of support material and bacterial strain tested. ${ }^{20}$

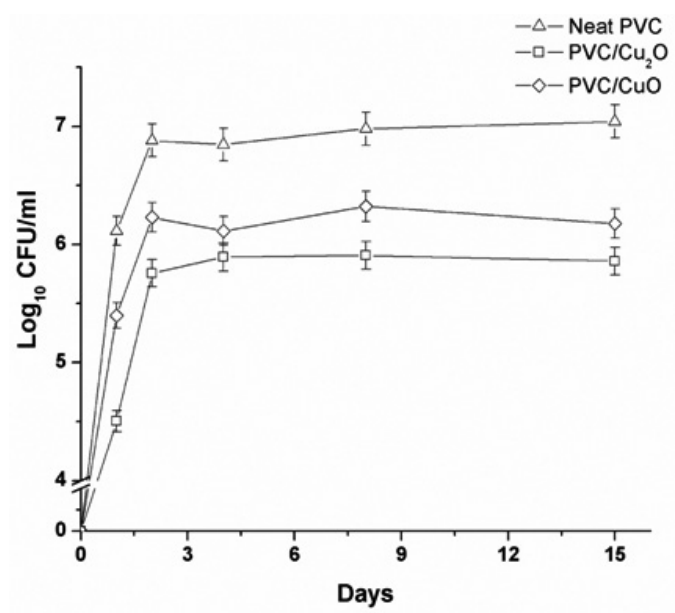

Figure 4. Kinetics of the biofilm formation E. coli ATCC 25922 on polymer ingredients. Number of bacteria adhered to neat.

\section{Effect of $\mathrm{Cu}_{2} \mathrm{O}$ and $\mathrm{CuO}$ on $E$. coli ATCC 25922}

The effect of $\mathrm{Cu}_{2} \mathrm{O}$ and $\mathrm{CuO}$ on morphology of E. coli ATCC 25922 was investigated by SEM and TEM analysis. Figure 5 shows the SEM images of E. coli ATCC 25922 incubated in the absence and presence of copper oxides 
( $320 \mu \mathrm{g} / \mathrm{ml}$, half minimum concentration to inhibit the growth of E.coli ${ }^{17}$ ). In all conditions, E. coli ATCC 25922 showed bacillary forms, however the average length of bacterial cell varied; in the absence of copper was 2.4 $\pm 0.4 \mu \mathrm{m}$ and in the presence of $\mathrm{Cu}_{2} \mathrm{O}$ was less, $1.7 \pm 0.2 \mu \mathrm{m}$ (see Figure $5 b)$. Unlike, E. coli incubated in the presence of $\mathrm{CuO}$, whose length, $2.1 \pm$ $0.4 \mu \mathrm{m}$ (see Figure 5c) was similar to $E$. coli cells incubated in the absence of copper $(2.4 \pm 0.4 \mu \mathrm{m})$. Similar results obtained Kundu et al. ${ }^{2.1}$ when incubating Magnetospirillum magnetotacticum in the presence of $\mathrm{Ni}$ and $\mathrm{Zn}$. Magnetospirillum magnetotacticum decreased its length when compared with bacteria incubated in the absence of metals.

The change in the size and shape of bacterial cells may be due to the alteration of membranes and/or cell wall, which can be determined using violet crystal at $1 \mathrm{wt}-\%$. This trial showed that bacteria incubated in the presence of copper oxides presented higher cell wall permeability (data not included). The increased permeability of bacterial cells in contact with copper may be associated to the release of copper ions present in the culture medium, altering the structure and integrity of the lipopolysaccharide, component of $E$. coli cell wall. Santo et al. ${ }^{22}$ reported that copper toxicity in bacteria such as E. coli is due to the increase of intracellular concentrations of $\mathrm{Cu}$ ions, which inactivates the several enzymes such as hydratases: dihydroxy-acid dehydratase (DVCI), isopropylmalate dehydratase (LeuC) and fumarase A (FumA), all are necessary for a normal cell function. In addition, $\mathrm{Cu}$ ions can damage $\mathrm{Fe}-\mathrm{S}$ cluster of proteins, resulting in defective cell growth. The results suggest that copper ions would act by inhibiting proteins related to the shape and size of $E$. coli. SEM images of $E$. coli ATCC 25922 incubated in the presence of $\mathrm{Cu}_{2} \mathrm{O}$, pores observed at their poles suggest these bacteria are probably non viable (see Figure $5 b$ ). However, further studies are needed to determine cell viability in the culture medium tested.
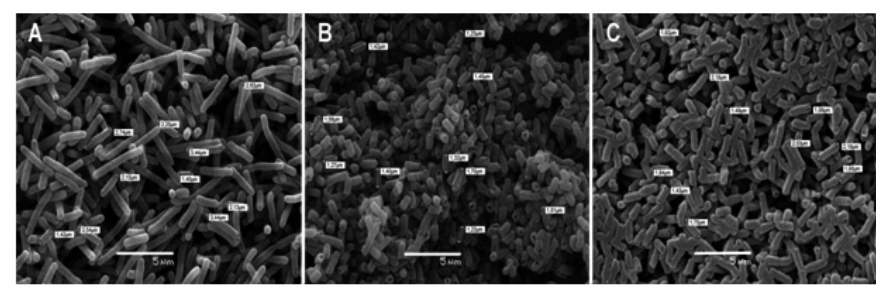

Figura 5. SEM images of E.coli ATCC 25922 incubated in the absence of copper (A), in the presence of $\mathrm{Cu}_{2} \mathrm{O}\left[320 \mu \mathrm{glmL}^{-1}\right]$ (B) and $\mathrm{CuO}\left[320 \mu \mathrm{glmL}^{-1}\right]$ (C). (X5000)

TEM images of E. coli ATCC 25922 incubated in the presence of copper oxides show that these bacteria has alterations in its membrane (see Figure 6), compared to that observed in E. coli incubated in the absence of copper oxides (see Figure 6a) where there are no signs of alteration at the membrane level. Figure $6 \mathrm{~b}$ shows the over-folding of the membrane of E. coli ATCC 25922 in the presence of $\mathrm{Cu}_{2} \mathrm{O}$. Similar results were observed in bacteria incubated in the presence of $\mathrm{CuO}$ (see Figure 6c). This study demonstrated through TEM images that membranes of E. coli ATCC 25922 are altered in the presence of copper oxides. Similar results reported Grass et al. ${ }^{23}$, demonstrating that cells are damaged in their cytoplasmic membrane and weakened in their cell wall a few minutes after incubation in the presence of copper. On the other hand, Rakhmetova et al. ${ }^{24}$ showed through electron microscopy that the metal microparticles and groups of them are located near the bacterial cell wall where they can liberate more toxic ions, which flow into the cytoplasm and can lead to cell death.
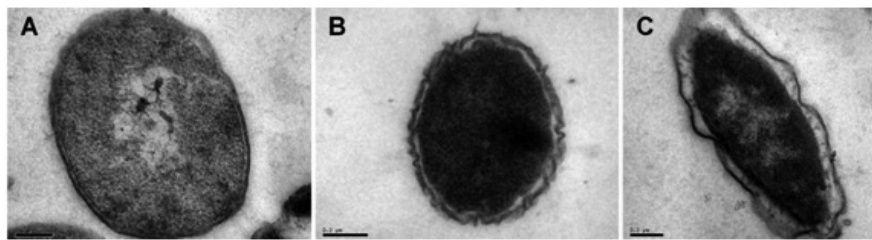

Figure 6. TEM images of E. coli ATCC 25922 incubated in the absence of copper oxide (A), in the presence of $\mathrm{Cu}_{2} \mathrm{O}[320 \mu \mathrm{g} / \mathrm{ml}]$ (B) and $\mathrm{CuO}[320 \mu \mathrm{g} /$ $\mathrm{ml}$ (C). (X 20000; black bar $=0.2 \mathrm{~mm})$.

\section{CONCLUSIONS}

$\mathrm{PVC} /$ copper oxide composites with $1 \%$ of $\mathrm{CuO}$ or $\mathrm{Cu}_{2} \mathrm{O}$ were obtained by using melt-blending method in a twin-screw extruder. The results of SEM-EDS $\mathrm{Cu}$-mapping indicate that the $\mathrm{PVC} /$ copper oxide composites are a hybrid of the copper oxide particles and the polymer matrix, where copper oxide particles are distributed uniformly in the matrix. This composite material inhibits the bacterial adhesion compared to neat PVC. The $\mathrm{PVC} / \mathrm{Cu}_{2} \mathrm{O}$ composite inhibits to a large extent the bacterial adhesion than the $\mathrm{PVC} / \mathrm{CuO}$ composite material. Copper oxides alter the membrane of Escherichia coli ATCC 25922 and reduce the length of the bacterial cell.

\section{ACKNOWLEDGMENTS}

The authors thank to Conicyt-Regional R08C1002, Programa de Financiamiento Basal para Centros Científicos y Tecnológicos de Excelencia, PFB-27, Sylex Chile Ltda. and World Compu companies; and Mrs. Johana Sanzana for sample preparation and testing.

\section{REFERENCES}

1.- B. M. Karandikak, B. L. Gibbins,K. A. Cornell, Patent WO 2006/015317 A2: Antimicrobial devices and composition.

2.- H. Imai and K. Kimura, Patent US 2010/0124562 A1: Antimicrobial composition, process for preparing the same, and utilization thereof.

3.- A. B. R. Mayer, Polymers for Advanced Technology 12, 96 (2001).

4.- X. Xia, S. Cai, C. Xie, Materials Chemistry and Physics 95, 122, (2006)

5.- A. Torres, C. Ruales, C. Pulgarin, A. Aimable, P. Bowen, V. Sarria, J. Kiwi, Applied Materials and Interfaces 2, 2547, (2010)

6.- M. Pérez, G. Blustein, M. García, B. del Amo, M. Stupak, Progress in Organic Coatings 55, 311, (2006)

7.- M. Heuser, C. Rivera, C. Nuñez, G. Cárdenas, Journal of Chilean Chemistry Society. 54, 448, 2009.

8.- Y. H. An, R. J. Friedman, Journal of Biomedical Materials Research: Applied Biomaterial 43, 338, (1998)

9.- R. M. Donlan, J. W. Costerton, Clinical Microbiology Reviews 15, 167, (2002)

10.- L. E. Castrillón, A. Palma, M.C. Padilla, Dermatología Rev Mex 54, 14 (2010)

11.- R. Gangopadhyay, A. De, Chemitry of Materials 12, 608 (2000)

12.- S. S. Ray, M. Okamoto, Progress in Polymer Science, 28, 1539, (2003)

13.- X. Chen, C. Li, L. Zhang, S. Xu, Q. Zhou, Y. Zhu, X. Qu. China Particuology, 2, 226 (2004)

14.- G. A. Gelves, B. Lin, J. A. Haber, U. Sundararaj, Journal of Polymer Science: Part B: Polymer Physics 46, 2064, (2008)

15.- F. H. Furkert, J. H. Sörensen, J. Arnoldi, B. Robioneck, H. Steckel, Current Microbiology 62, 1743 (2011)-1751.

16.- R. A. Herbert, Methods in Microbiology 22, 2, (1990)

17.- G. Ren, D. Hu, E. W. C. Cheng, M. A. Vargas-Reus, P. Reip, R. P. Allaker, International Journal of Antimicrobial Agents 33, 587, (2009)

18.- S. Divya, M. Masilamani Selvam, International Journal of Environmental Sciences 2, 1, 2011

19.- M. A. Mondaca, V. Campos, R. Moraga C.A. Zaror, The Scientific world Journal, 2, 972, (2002)

20.- M. Katsikogianni, Y.F. Missirlis, European cells and materials 8, 37 (2004)

21.- S. Kundu, A. A. Kale, A. G. Banpurkar, G. R. Kulkarni, S. B. Ogale, Biomaterials 30, 4211, (2009)

22.- C. E. Santo, E. W. Lam, C. G. Elowsky, D. Quaranta, D. W. Domaille, C. J. Chang, G. Grass, Applied and Environmental Microbiology 77, 794 (2011)

23.- G. Grass, C. Rensing, M. Solioz, Applied and Environmental Microbiology 77, $1541(2011)$

24.- A. Rakhmetova, T. Alekseeva, O. Bogoslovskaya, I. Leipunskii, I. Ol'khovskaya, A. Zhigach, N. Glushchenko, Nanotechnologies in Russia 5, 271, (2010). 